\title{
The Representations of Kurdish Women in Selected Turkish Novels
}

\author{
${ }^{1}$ Gharbi Mohammed Mustafa. ${ }^{2}$ Kawyar Yaqub Ahmed \\ ${ }^{1}$ Department of Translation, Nawroz University, Duhok, Kurdistan Region of Iraq \\ ${ }^{2}$ Faculty of Humanities, University of Zakho, Duhok, Kurdistan Region of Iraq
}

\begin{abstract}
The representations of minorities by the mainstream writers have frequently been viewed negatively. The depiction has been of a major concern to the literary writings. However, the representations of Kurdish women in Turkish literary works has rarely been tackled in scholarly papers and researches. Generally, the life of a Kurdish woman is molded by patriarchal practices, traditions, and customs that govern all social zones, rather than the legal rights. The patriarchal ideologies embedded in women's mind make them believe that they could do nothing but what is expected from them; to be submissive and obedient.

This research paper focuses on the representation of the Kurdish women in selected modern Turkish novels by three particular Turkish novelists: Honor (Penguin, 2012) by Elif Shafak written in English language ; Face to Face by Ayşe Kulin (Everest, 2006) written in Turkish ; The Legend of Ararat (Collins and Harvill Press, 197) by Yashar Kemal written in Turkish . The research aims at selecting a variety of authors based on gender, ethnicity, Language and region. Yashar Kemal, is a Turkish writer of a Kurdish origin from Gökçedam, a village in the southern province of Osmaniya; Elif Shafak, is a Turkish-British writer who lives abroad and Ayşe Kulin, a woman writer from Istanbul.

By means of textual analysis, the study investigates the representation of Kurdish women in these texts. Through a comparative approach, the paper endeavors to examine the ways in which the selected authors depict the Kurdish women and their social predicaments in their fictional works. Moreover, it investigates the images and conditions these authors depict to the mainstream Turkish readers as well as to the public readers in the rest of the world. This is portrayed through the construction of specific female characters that enhances a stereotype Kurdish women, who are powerless, submissive, ignorant and victims of the patriarch Kurdish society in southwest Turkey. It also explore the diversity in the authors' representation; the sympathetic to the Kurds, challenging the stereotypes viewpoints of the Kurdish women or the negative image and the harsh representation that includes depicting misconceptions and defects in the construction of the Kurdish identity and social structure. The women in the novels are presented as victims of the gender-based system simply for having been born female; they are marginalized and discriminated against in a variety of ways.
\end{abstract}

Keywords: Kurdish women, Minority Representation, Turkish writers

\section{Kurdish Women in Turkey}

The women's situation in the Kurdish areas in Turkey has long been and continues to be connected with the conflict that has plagued the regions. As a result of the conflict between the Kurdistan Workers Party (PKK) and the Turkish military reigned in the southeast; many Kurdish towns and villages were demolished by state security forces. Hence, Kurdish villagers were displaced from their homes and forced to flee to nearby cities. These families' sufferings affected females who, suffered from social, political, cultural and economic hardships, and the struggle to improve their conditions. There are no dependable statistics of the number of people who have been killed as a result of the conflict. Nevertheless, there are thousands of Kurdish girls without fathers, widows, and wives of the 'disappeared' and many older women who are both widowed and have lost the sons and grandsons who would have supported them (Bernu 4).

Socially, the lives of Kurdish women in southeast Turkey are shaped by patriarchal practices, traditions and customs. In a traditional Kurdish community, a woman's position and living are entirely dependent on 
her marriage. Getting married is considered an ideal situation for women. There are rare jobs opportunities for women outside the home in Kurdish areas; therefore, marriage is the only way for a woman to support herself. The worst thing that can happen to a woman is infertility because most Kurds are from poor remote villages and cannot afford treatments (Saarinen 4).

Kurdish women suffer from honor-killings. Men's 'honor' is largely determined by their own behavior and the behavior of their mothers, wives, sisters, daughters and relatives. Therefore, it's important for women to maintain their honor; the modesty code is a central part of their identity and way of life. If their honor is tainted, the head of the family will kill the girl in order to restore the honor of the family (Adli 34).

Kurdish women in remote areas encounter difficulties accessing hospitals. Being women of a stateless nation, they have always been subsumed under the categories of the dominant state authorities. Therefore, statistics on Kurdish women's health and their access to healthcare are hardly available. As a result of discriminative state policies towards the Kurds, the state authorities did not show any interest in investing in the infrastructural development of the Kurdish region - including health services. Therefore, many women do not have access to hospitals (Bernu 61). Furthermore, girls face a range of human rights violations, especially in the poorer regions. Among the most extreme violations is their inability to go to school or complete their education. Kurdish girls are often unable to join school for a number of causes, including poverty and a lack of suitable education facilities (Stevenson 70).

Lastly, Kurdish women face racism in Turkey. FeyzaBurak Adliin her article shows the discrimination the Kurdish women face for resulting from veiling her heads. On her third visit to Cibo ${ }^{12}$, she suffers from food poisoning and was hospitalized in Erzurum. Because she was dressed like a woman from Cibo and was covering her head with a veil, she received a ruthless treatment from the doctor. She describes the treatment she receives as "traumatizing" and says: "After listening to my symptoms without even looking at my face, the female doctor talked to me in a condescending manner...In short, the doctor without troubling herself to explain anything to me, had ordered me to be hospitalized for a day to receive an IV treatment". Only after Feyza tells the doctor that she is a graduate student from U.S and that she is not a local woman, the doctor's behavior towards her changed, apologized for her previous demeanor, and began treating her more respectfully. This experience gives a hint to the ways in which rural women are treated in the city (59).

\section{The Four Selected Novels: Short Summaries}

\subsection{Elif Shafak's Honor: Plot Overview}

The novel Honor is about the lives of the twin sisters, named Pembe and Jamila, born in a Turkish village populated by the Kurds. The novel begins with Esma on her way to pick up her brother Iskender from the prison where he's been imprisoned since 1978 for the murder of their mother, Pembe. Esma offers up fragments of family history, beginning with her mother's birth in a village near the Euphrates. She describes a world where women as well as men enforce an honor code that results in the social death of men who fail to act like men, and the actual death of several female relatives. When her family migrates to Istanbul, and then to London in the early 1970s, they maintain this norm and value of honor.

Originally, Adem falls in love with Jamila, but when he learns that she has been kidnapped, he prefers to marry her sister Pembe instead. In London, Adem gambles away their savings and deserts Pembe to live with his mistress. Pembe takes a job at a hair salon and begins to blossom. Then Pembe meets a nice man, Elias, and falls in love with him. When Jamila knows about this 
and senses that her twin is in danger, she seeks the people who can get her to London without proper documentation in order to prevent her sister from doing any mistakes.

Because Adem is away, tradition dictates that Iskender, the eldest son, is now the head of the household. Iskender must step in and become the one who will not let any shame come to the family name. He feels compelled to save the family's honor. Therefore, when he learns about his mother going out with a man, he stabs Jamila on the right side of her body thinking that she is his mother. Jamila instantly dies because her heart is situated on the right side of her body, while Pembe's heart is on the left side of her body.

\subsection{Ayşe Kulin's Faces to Face: Plot Overview}

In her novel Face to Face, the Turkish author Ayşe Kulin narrates the life stories of two women who are from opposite spectrums of the Turkish society. She explores the Kurdish question, through a long interview between the Turkish journalist, Nevra, and the Kurdish activist in prison, Zelha. In this interview, the two discuss the reason that has put the Turks and the Kurds on opposing sides. As the conversation continues, both of them get tensed and Zelha rushes to leave the interview, but Nevra stops her and tells her that they used to be best friends in their childhood.

When Zelha remembers her, the interview continues. Both of them tell stories of their past in the Kurdish village, Saricadam. Zelha narrates her elopement with Alisan, her marriage to her current husband Siyar, and the tragic story of her cousin Cengiz. While Nevra describes her divorce and her illicit relationship with a married man. Thereafter, they both continue to discuss the problems and difficulties the Kurds face in their poor remote villages. And they try to find a solution for the existing problem between the two opposing sides. At the end of the interview, Nevra finds out that the problem between the Turks and the Kurds can be solved through dialogue and offering compromises from both sides.

\subsection{Yashar Kemal's The Legend of Ararat: Plot Overview}

One day, the young Ahmet finds, in front of his humble home, a very precious horse with a beautiful saddle embroidered with gold and silver, suggesting that its owner is of good will. At that time, the tradition states that if a horse chooses the door of a house and stands there, it means that it is a gift from heaven to the owner of the house. The custom also demands that the owner of the house leave the horse three times; if the horse returns, then the house owner can have it. Depending on this, Ahmet claims the ownership of the horse.

The owner of the horse, Mahmut Khan, the Pasha of the village of Beyazit, orders his men to return the horse with a message that he is willing to pay Ahmet as much money as he wants. But Ahmet is willing to give his own life rather than return the horse back. The Kurdish Beys intervene to solve the dispute, but the customs are stronger than all mediations. The cruel Mahmut Khan launches an attack and starts searching for Ahmet and the simple people who fled with him, after the threat, to the Hakkari area where Shemdinan Kurds live. The campaign fails to find the horse, and the attackers find only an elderly sheikh nicknamed "the Sofi" and they imprison him. The pasha has three daughters, Gulistan, Gulriz, and Gulbahar. Gulbahar risks her life and visits the prisoner, the old Sofi to learn the story of the young Ahmet who has refused to obey the orders of her father. The Pasha learns where Ahmet is hiding and sends a messenger that he is pardoning Ahmet and the villagers. However, when Ahmet returns, the pasha breaks his word and imprisons him. He gives him forty days until he returns the horse or he will be executed. Gulbahar meets her lover Ahmet in the prison. This would not have been possible without the sympathy and help of Memo, the head of the jailers. After many secret attempts 
by Gulbahar, the horse is recovered, but the Pasha says that it is not his horse. The deadline for execution is coming close. Towards the end of the last day, Gulbahar pleads Memo to release Ahmet and his friends. He agrees in exchange of a lock of her hair. Gulbahar agrees. After the prisoners are released, Memo kills himself.

Despite the approval of the Pasha, after the insistence of the people, and the pressure of crowds, the pasha approves the marriage of his daughter Gulbahar to Ahmet under the condition that he climbs the mountain Ararat and return. Though no one before has reached the summit of the mountain and returned safely, Ahmet agrees to carry out the impossible condition of the Pasha. He goes to the top of the mountain, sets the fire there to signal his arrival, and the people start the celebration. Ahmet knew that Memo did not release him for nothing, and when he learns that Gulbahar was ready to give Memo herself as a price for Ahmet's life, the fire of the love is extinguished in the heart of Ahmet. The story of love ends on the banks of Lake Kup at the bottom of Mountain Ararat, where Ahmet is missing in the blue of the lake and Gulbahar remains waiting for his return in vain.

\section{The Conditions of Kurdish Women in Turkish} Fiction

Traditional gender roles cast men as "rational, strong, protective, and decisive; they cast women as emotional (irrational), weak, nurturing, and submissive" (Tyson 85). It programs women to accept their gender roles passively and submissively. This is why most women, in the selected novels, live their lives to serve the typical female role because they believe in their weakness and think that they should be submissive as a part of her role. However, some "Women are not passive victims of oppressive structures; they have struggled to change their circumstances" (Walby 200). Both types can be seen in these novels. The writers explore this issue in their works and depict women's lives. Each of the female characters in the novels has a different characterization. Yet, all women are objectified, used, mistreated, rejected and victimized. All of the women end up with unhappy endings. None of Shafak's women characters, except for Esma, survive the story events. In her novel, the women's right to live is conditional to their obeying social norms and traditions. And Zelha, Kulin's character, ends up in prison for an unknown period of time. While Gulbahar, in The Legend of Ararat, is abandoned by her lover Ahmet.

\subsection{Code of Honor}

Shafak presents honor in her novel as a basic dimension of Kurdish culture, where a person's honorable deeds are looked upon as an asset. It is not an individual attribute. It belongs to individuals as members of families and social groups. If one member of the family commits a reprehensible act or fails to behave according to the code of honor, the whole members of the family could lose their honor.

There are various definitions of honor. The most impressive definition for honor in a traditional honor culture is Salzman's definition. He focuses on honor as "public opinion's judgment of one's actions" (Cross 233). In the Kurdish community the opinion of people matters. If the honor of the family is threatened, the family will actively defend their honor through honorkilling; believing it could be only restored in this violent way. Family killings of women are a consequence of too much concern for reputation and social respect.

Women murdering in the name of honor is a genderspecific form of discrimination and violence. It is a part of a community mentality. It is based on the deeply rooted belief that women are objects and possessions, not human beings entitled to rights equal to those of men. Women are considered the property of men and are seen to symbolize the honor of the men to whom they 
belong. If a woman or girl is accused or even just suspected of engaging in behavior that could taint the family's name and status, she will face brutal retaliation from family. Even though sometimes such accusations are baseless, any accusation of dishonor against a woman is sufficient for family members to take matters into their own hands.

Honor-killings occur frequently as a result of extreme patriarchal views on women and outdated tribal practices. In that tradition, the chastity and virtue of the female members of a man's family is the main component of his honor. When the honor of the man is threatened because of the misconduct of a female member of the family, many believe honor can be regained by murdering the wrongdoer. Although there are no justifications in Islam for 'shame killing' of women, it remains a part of the patriarchal culture under the name of religion and traditions. The first character who is a victim of this patriarchal ideology is Hediye in Shafak's Honor.

\subsection{Women as Victims of Code of Honor}

The Kurdish culture, as any other culture in the world, has its own traditions and beliefs, some of which are beneficial, while others are harmful to women. These damaging practices include polygamy, honor-killings, son preference, child marriage and early pregnancy. The women in Shafak's Honor, Kulin's Face to Face, and Kemal's The Legend of Ararat are presented as victims of the code of honor.

The first victim is Hediye. She is a victim of honor killing. After Naze's death, Hediye, as the eldest daughter in the family, becomes a mother to her younger seven sisters and spends her childhood taking care of them. She never complains about her unending responsibilities and accepts her role. Even after their father remarries, the girls still see Hediye as their mother and the new woman only as father's wife. Hediye never had a moment for herself; so when she falls in love with a medical man, she defies all the limits imposed on her by her patriarchal society and religion and elopes with him. Her strive for freedom and eagerness to live a life with a man of her own choice instead of entering an arranged marriage emboldens her to risk her own life for it. However, the medical man breaks his promise of marrying her and abandons her upon his family's opposition. Though the reason for the opposition is not disclosed, it is clear that the reason is because she is just a poor Kurdish girl from a poor abandoned village who can never be a proper match for their smart and cultivated son. Hediye returns home and regrets her actions and asks her father for forgiveness but he folds back and says:

If I had a son, I'd ask
him to kill you and
clean our family's good
name. And your
brother would go to jail
because of you. He
would spend his life
rotting amidst four
walls (Shafak 266).

The next day Hediye hangs herself with the rope her stepmother served to her in the cauldron as planned by her father. This view that violence can be justified in the name of honor and shame exists traditionally in some Kurdish villages. When the honor of the family is threatened because of the misconduct of a female member of the family, people are readily willing to kill their own family members to protect their honor because their culture breeds the idea that honor is more important than life. Berzo, feeling disgraced by his daughter, barely leaves his house and spends his days sitting all day long at home. He believes that his honor can be regained only by his daughter's death. This is why he makes his own daughter commit suicide so that 
the good reputation of the family will be restored and the shame will be washed away. And only after deciding his daughter should die, he started to go out in public believing that his honor now is regained and washed from stains:

The next morning Berzo had his breakfast later than usual. As he sipped black tea and chewed his flatbread, the girls waited. 'I'm going to the tea house,' he said, without meeting anyone's eye. Upon hearing this, Pembe felt a rush of panic. Their father had not entered the tea house since the day Hediye had run away. What had changed now to make him go there? 'What will I do with her under my roof?' Their stepmother grumbled. 'you know what to do,' he said and said no more( Shafak267).

The twin sisters, Pembe and Jamila are also presented as victims of the code of honor. They live in a village where men have honor, even if they do dishonorable things, and women have shame, even if they have done nothing shameful. Honor has substantially different expectations for each sex, and women have more to lose from moral missteps than do men. This double standard norm leaves devastating effects on the sisters, especially Jamila. After an incident of the twin's impudence, Naze feels the need to instruct both about women's modesty. She explains that God has created men and women from different fabrics: one superior to the other. Men are created from dark fabric, which does not stain; while women from the lightest cambric, which shows every speck of dirt. Because of this, an unchaste woman is worth no more than a "chipped kuruş"1. Though Jamila does not internalize this patriarchal ideology, she remains a cautious modest woman. Nonetheless, her society condemned her as a woman with tainted honor because of her kidnapping incident. Her elder sister, Kamila, was engaged to be married. Her father called off the wedding due to a fight between the two families. In retaliation, the groom's family kidnaps Jamila. Hence, Berzo consents to Kamila's marriage in return for Jamila. Though Jamila is still a virgin, he decides to marry her off to a widower to save her honor. A year later, Adem meets Jamila and falls in love with her. On the proposal day he finds out about this incident and decides to marry her sister Pambe instead because of Jamila's tainted honor. Her kidnapping is a stigma in the Kurds areas and she is doomed to have a tainted honor for the rest of her life. She has done nothing shameful and yet she is being punished and judged. It is the kidnappers' honor which should be tainted for doing such a dishonorable act, but in that patriarchal society males' honor has no stains.

So it was that in the land Pink Destiny and Enough Beauty were born. 'honor' was more than a word. It was also a name. You could call your child ' honor', as long as it was a boy. Men had honor. Old men, middle-aged men, even schoolboys 
so young that they still

smelled of their

mothers' milk. Women

did not have honor.

Instead, they had

shame. And, as

everyone knew, shame

would be a rather poor

name to bear

(Shafak16) .

In London, Adem's absence becomes more frequent till he disappears without notice. Pembe accidently meets a man and starts to see him. For the first time, Pembe has been treated nicely and as an equal human being by a man. Far before she meets Elis, she has asked her husband for a divorce, but he has neglected her request. Has her husband been at home, she would never have seen another man. So basically its Adem's fault, however, nobody blames Adem for his wrongdoings including abandoning his responsibilities towards his wife and family, gambling, cheating on his wife with a Russian dancer, and giving money to the dancer rather to his family. In a patriarchal system, it is always the females' fault, men are never wrong. Tariq tells his wife that it's Pembe's fault for Adem's absence:

She knows that he's
moved in with another
woman
Well, what do you
expect, if she's not
woman enough to keep
her husband home.
Tariq said, leaving the
sentence unfinished
(Shafak153).

Everyone starts gossiping about Pembe'shonor, therefore, Tariq convinces Iskender to clear his family honor and her son Iskender decides to punish her.According to Iskender, his mother had brought him stigma and dishonor by spending long hours away from home and repeatedly seen with another man, Elias. She has brought disgrace to the family. Since he considers himself the man of the house, he decides to set things right and restore the honor of the family. He stabs Jamila from the back, thinking she is his mother, and she instantly died.

In honor-killings, everyone is a victim. In this case, even the killer is the victim of perceived expectations and responsibilities that model his behavior as clearly as the double standards that rule the patriarchal society. For his crime, he spends most of his youth years at prison and his whole future is ruined. At the prison, he suffers from guilt and regrets his decision every day. Iskender at first was hesitant; he was encouraged by his uncle Tariq, to kill his own mother. He was only sixteen years old and was easily brainwashed by patriarchal ideologies that if he has no honor then he is not a man. As if the only way to be a man is to be a patriarchal man, and if he is not, then he is weak and unmanly. Thus, by his crime, he tries to please the society. Gaining pride and esteem will fulfill his traditional role for being an honorable man:

I told him I had punished Mum for her illicit affair. From now on she'd never do such a thing. I said her wound wasn't too bad but it would take some time to heal. I had stabbed her once on the right side of her chest. That would show how grave her $\sin$ was. It would give her time to 
think about her

mistake, to repent. And

the man would be

scared out of his wits.

He would leave us

alone. Our family's

honor was cleansed.

'What have you done, son? His voice sounded strangled.' This is terrible'.

I was taken aback.

“Bb...but...we...ttt...al

k...e

dab...ab...ou...ttt...thi

s'.

'Surely we did not,' my

uncle said.

The man who told me everything and then impressed me, over and over again, that I had to do something and do it soon, had vanished thin air. I was stunned (Shafak 248)

In Kemal's novel, Gulbahar is also presented as a victim of the code of honor. She loves Ahmet deeply and is willing to do anything to save him. She stands against her tyrannical father and risks her life for the sake of saving Ahmet. Ahmet repays her courageous act by abandoning her. He believes she has stained her honor by offering Memo, the jailer, anything he wants in exchange for releasing him from prison. Even though Memo didn't ask for a dishonorable thing, her honor is lost just for suggesting the offer. In a male-dominated community such an offer is considered disgraceful and reprehensible. Honor is more valued than the life of a person, and women's honor is a symbol of the man's honor. If Ahmet chooses to stay with her and break the traditions it will mean that he is a dishonorable man.

I told him, she said, 'that I was ready to give him anything he wanted in exchange for your life. He asked for nothing.'

'You told him you would give him whatever he asked of you, is that so?'

I said I would give him anything he wanted," she said again. 'And he never asked for a single thing' (Kemal 153)

\subsection{Women as Submissive Beings}

The feminist critic Germaine Greer ${ }^{2}$ points out that patriarchy has weakened women and shaped them according to male desire and vanity. She stresses the fact that socio-cultural conditioning has made women naively and unthinkingly consent to patriarchal assumptions of themselves as the natural way of things. Greer goes to the extent of saying: "women represent the most oppressed class of life...., for whom slaves is not too melodramatic a description" (Greer 369). This can be illustrated in the character of Naze in Shafak's Honor. . She is a very passive, naive and ignorant woman. Not only her speech demonstrates passivity but also her actions. She is viewed as someone who is to be submissive to the family and society's demands; in her point of view refusing them will result in problems for her. For example she is upset with the girls going to school. Her husband tries to explain to her the 
importance of education and that it will enable their daughters to read the constitution and know their rights, and so "If one day their husbands treat them badly, they won't have to put up with it. They can take their children and leave" (Shafak11). Still, Naze does not see any point of it and is so ignorant that she does even know what a constitution is. She prefers her daughter to be married instead of educated. The most important role for her daughter in the society is to be a wife. Whenever one of her daughters crosses a line, she would punish them by smacking them with a wooden rod, though never on their faces for a girl's beauty is her dowry. This demonstrates that not only she is submissive, but wants her daughters to be submissive to their husbands as well and accept spousal abuse in order to be provided for.

She'd rather see her daughters hurt than see them disobedient. In her mind if a wife tries to liberate herself from her submissive role, she will immediately be considered as a bad and immoral person. Naze is a patriarchal woman, "a woman who has internalized the norms and values of patriarchy"(Tyson85). Such characters in a patriarchal society are even more dangerous than the male ones. They are one of the main reasons for keeping these primitive values deeply rooted in the community's mentality. They teach and educate their daughters to be obedient, dutiful, and devoted for the male characters, even if they mistreated or abused by them.

Naze is a kind of woman who, no matter how much she suffers from the discrimination, accepts it instead of struggling against it. Her attitude of accepting gender discrimination is influenced by the strong patriarchal ideology developed in her society. The strong influence of patriarchal ideology on her is caused by her lack of knowledge and education.

Pembe is also presented as a submissive woman. She is deeply affected by her mother's character and becomes a second version of her, imprisoned and constrained by ideologies of patriarchy. Her mother has implanted the patriarchal belief that the woman's main role in life is to be a wife. Pembe has internalized this ideology, therefore, she accepts marrying Adem; even though she knows that it will deeply hurt her sister Jamila. She marries Adem to fulfill society's expectations and to accomplish her traditional gender role. She believes living life based on communal messages is what means to be a woman. She also believes that through marrying Adem, she will gain happiness as she considers Adem is her only ticket out of her poor, marginalized village. However, her acceptance leaves a feeling of guilt for the rest of her life. She keeps in touch with her sister and asks for her forgiveness. She writes in the letter:

$$
\begin{aligned}
& \text { I should have never } \\
& \text { married him. It wasn't } \\
& \text { in my hands, but I } \\
& \text { didn't prevent it... } \\
& \text { Jamila, you must be } \\
& \text { upset with me, are you? } \\
& \text { I would be, if I were in } \\
& \text { your shoes (Shafak 90). }
\end{aligned}
$$

Her letter reveals her feelings and validates the fact that she knew what she did was wrong; nonetheless she thinks that she had no choice but to submit. Patriarchal society keeps inserting views that men are powerful and women are powerless. Thus, Pembe believes that she is powerless and has neither capability nor strength to fight against men and their decisions. Additionally, she obeys her father's decision to marry her off to due to fact that if she disobeys a parental decision that will make her a misfit and disobedient child which will in turn taint her character.

As a wife, Pembe is submissive and obedient. She does her duties in the household without wishing any wage but comfort and a happy marriage. Adem does not love 
her, he does not give her a happy marriage and for the most time, he is absent gambling his money. Pembe does not complain and keeps her duties. After Adem loses his money in gambling, Pembe does not object working as a maid for rich people since it's her job as a wife to support and help her husband even if he is unfaithful to her and mistreats her. She takes care of their children, cooks their meals, and cleans their homes. She works for several families till she finds a full-time job working at a house of a famous actress. The actress did not pay her wage in the due time. Her son says "Mum expected to get her wages any day, but there was no mention of it and she was too shy to ask"(Shafak 76).The reason behind Pembe's not asking for her money is because for her entire life she never asked for her rights. She was raised by patriarchal ideologies that taught her she has no right to ask for her rights. One day, the actress's husband comes back home drunk and he sexually harasses her. Pambe pushes him away and runs out without taking her wage. She did not tell her husband of the incident because she knows that even though she is innocent, her honor will be tainted just like what happened to her sister Jamila.

Pembe's submission to patriarchy also can be seen in her way she raises her children. She raises them as patriarchal mothers raise their children. She raises her son, Iskender, as the sultan of the house and this will ruin her happiness and work against her in the long run. After immigrating to Britain, Adem's absence becomes more frequent till one day he disappears without notice. Since the father is not present, Iskender appoints himself as the head of the family. The son wants to take over the father's place in the family, and because his father is absent, he considers himself the head of the family. He puts himself in charge of the household. He asks his mother to quit her job at the salon. Pembe obeys him and does not stand up against him. From being submissive to her husband, she becomes submissive to her son. She is always submissive to the male members of the family that is how she has been raised and how she raises her child, to be a typical patriarchal man. Pembe notices that she has raised her son just like the men of her village have been raised.

The men she knew
would barely enter the
kitchen to get a glass of
water for themselves,
which now that she
thought about it, was
also how she had been
raising her two sons,
especially Iskender

(Shafak 117).

Patriarchy subordinates the female to the male and treats the female as an inferior being, and this power is used, directly or indirectly, in civil and domestic life to constrain women. Because Pembe educated Iskender to be a patriarchal man, he tries to dominate his sister too with the justification that he does it for her own sake. Esma refuses and blames her mother for his actions. She tells him:

Who says you have to
take care of me... I can
take care of myself,
thank you very much.
It's all Mum's fault. She
raised you like this.
Malamin, Berhamin.
And now you think
you're the Sultan of
Hackeny (Shafak 218).

Though Esma was reared up by a patriarchal mother, she grows to be an independent strong woman who does not fear standing up for her rights. She loves reading and has 
a liberated personality. Pembe worries that "her eyesight- and options for marriage- would be ruined because of too much reading" (Shafak 135).This point proves that the education alone is not enough for a woman to be educated. Pembe has been educated at school, but because the environment in which she grew up in and all the women she has been acquainted with were uneducated, her personality has shaped to a submissive patriarchal one. Signs of change in Pembe's personality only appear when she travels to a different environment and meets different educated people. Esma's individuality is a result of both, education, and educated environment.

It is important to mention that Pembe's representation changes through the end of the novel. After immigrating to Britain, she starts to change gradually and tries to form a new identity. Her sister-in-law, Meral, notices this change in Pembe.

$$
\begin{aligned}
& \text { There was an } \\
& \text { independent streak in } \\
& \text { Pembe that she couldn't } \\
& \text { quite put her finger on- } \\
& \text { an undertow of } \\
& \text { unruliness in a sea of } \\
& \text { calm (Shafak231). }
\end{aligned}
$$

Pembe accidently meets someone. Hesitantly, she starts seeing him secretly and starts to have feelings for him. She decides to find a lawyer and file for divorce. Pembe's plan of changing herself and her life for the better is her first step towards transformation from a patriarchal woman to an independent strong woman. In her book, Tyson calls herself a recovering patriarchal woman because she learned to recognize and resist the patriarchal programming that she has internalized years ago (86). This can be said about Pembe too. Her decision to change herself and live her life regardless to patriarchal rules is a sign of her recovering from the social programming that she had also internalized from her mother and society. In her community, it is a taboo to ask for a divorce, women have to be devoted to their husbands and bear her situation no matter how agonizing and unbearable it is. But Pembe does not care anymore about these principles and resolves to correct her mistakes and alter her life for the better. There are two main factors for women's submission.

\subsection{Educational Deprivation}

Education is one of the most basic and fundamental rights of a human being. It brings enlightenment and empowerment. If someone is deprived of this simple right, all paths, leading to improvement, success, and a better life, are blocked. In these novels, in the Kurdish villages, Mala Car Bayan ${ }^{6}$ and Saricadam7, large proportion of women are either denied this right or do not have access to education. This educational deprivation exists due to several factors. The first one is that society doesn't encourage their females to leave home and have education. Its patriarchal ideology dictates that the role of a woman is merely to be a wife and mother. Families see no use of education since all of their daughters would eventually get married. Naze is one of the women who believe that her girls' education is futile and worthless since it won't help them get married. Kader Ana, Zelha's mother, also dislikes her girl getting educated. She hides Nevra's letters from her daughter fearing that she will encourage and persuade her to stay with Nevra in order to get in a primary school. And of course in these villages, a mother prefers to see her daughter married rather than educated.

The more important reason is the lack of educational facilities. If schools are not available or accessible, then even the interested parents cannot send their daughters to school. The Kurdish village, Mala Car Bayan "House of Four Winds", has no schools. Therefore, families do not send their daughters to school. In fact, Berzo is the 
only man who sends his daughters to school. Pembe and Jamila had to walk forty minutes every day to school, "a decrepit one-storey building in another village" (Shafak 10). Their shoes start to wear out and Berzo couldn't afford to buy a new pair of shoes due to the poverty of the family. So high intensity of poverty and parent's inability to bear and afford the expenses of their girls going to a distant school is another major factor of educational deprivation. The lack of schools is also found in Saricadam village. Zelha is ambitious and eager to pursue her education in a school. She tells her friend that she "desperately wanted to finish primary school, as you know, there was not a fourth form in our village school" (Kulin 49). Therefore, she couldn't continue her education in a school and had to study at home. The children of the villages near Kars, Erzurum and Dogubeyazit had to walk in the snow for five to ten kilometers wearing shoes with holes in the soles. Nevra tells her friend about the story of a little Kurdish girl struggling to get her education:

Can you imagine Zelo, a forty-kilometer round trip between home and school every day? She was almost freezing and yet her eyes were smiling. Do you know why? Because she was going to school (Kulin 237).

Last but not least, society feels that education is only required when someone has to work outside home and girls do not have to work since husbands will take care of them. However, even if the girl is fortunate enough to finish her education and is allowed to work outside, she won't find a proper job in such disadvantaged villages. Shafak describes the village as" it was rugged, remote Kurdish village with no roads, no electricity, no doctor, no school" (Shafak 6). For these reasons, education is marginalized and women are oppressed deprived of this basic human right.

The Kurds have historically experienced discrimination in Turkey. The main way in which the Turkish state discriminates the Kurds is through language and education. When the Kurds are in public institutions, such as hospitals or schools, they are ill-treated and face racism. Turks deal with Kurds as they are inferior human beings.

The Kurdish students are abused at school. Students' abuse can come in many forms and may involve situations that are not necessarily physically abusive. For example, the twin and all other Kurdish students face racism and discrimination based on their race. The Turkish teacher, who resented having been sent to the village, introduced a set of rules for the eight years old student. The main rule is that whoever uttered a word in Kurdish would have to stand on one foot by the blackboard and many students had to spend hours in the same position. This shows that Kurdish children face brutal treatment in their daily lives. Most of the villagers are poor and suffer from their difficult lives. Still, they have hope and send their children to schools in order to make them have a better life than theirs. Unfortunately, teachers do not take their circumstances into consideration and do not care about these people. They treat them as inferior human beings. Generally, mistreating child students is against the law. In Turkey, physical punishment has been considered illegal in schools since 1923. The State Personnel Law No. 657 provide for punitive measures against teachers who use physical or psychological violence against children. A teacher who commits a harmful act against a pupil may face the punishment of non-payment of his/her salary (Global Initiative 5). However, these laws are not applied in these forsaken areas because no one cares about how Kurds are treated.

Pembe did not only face racism at school but also at the hospital. When she was a little girl, she was bitten by a dog. Her father took her to a hospital in Urfa, since there 
were no hospitals within sixty miles. This quote exemplifies the way Turks treat Kurds.

The doctor gave the

father and daughter no

more than a grudging

glance. It was as if their

mere existence tired -

even saddened - her.

They were clearly the

last people she wanted

to treat at the end of

this arduous day. She

did not talk to them

much, letting the nurse

ask the important

questions (Shafak 12).

The persistent constraints and deprivations that prevent women from getting education have huge consequences for individuals and communities. It has deeply rooted personal and social consequences. Those consequences are more serious on females than males. For example, educational deprivation reinforces patriarchal ideology and thought. In a male-dominated society, the subordination of women and gender discrimination exists because of women's acceptance. Women obey men and their patriarchal principles because of their ignorance and unawareness of their rights. Because Naze is uneducated, she is easily influenced by the patriarchal ideology. She has internalized the ideology and tries to implant it in her daughters. In her point of view, her daughters should endure sufferings in every condition, even if they are badly treated by their husbands, because it is improper for women to oppose men. In a discussion between her and her husband she says:

No daughter of mine

will abandon her husband. If she does,

I'll beat the hell out of her, even if I'm dead by then. I'll come back as a ghost. (Shafak 11).

This confirms that the system of patriarchy functions and prevails because of women's educational deprivation. The survival of patriarchal ideology will result in the persistent of early marriages, honor-killings, polygamous marriages, and female oppression.

Because Kader Ana is uneducated, she encourages her daughter to accept the marriage proposal of a man who is much older than her. The educated Zelha is disgusted by him and refuses to obey her uncles and mother orders. She elopes with Alisan, the boy she is in love with. Unfortunately, he falls in love with another girl and brings her home as a "kuma"and starts to ignore Zelha. Zelha couldn't bear being treated as an inferior human being and decides to return back home. Had she been uneducated, she would have tried to put up with the situation thinking she has no alternative and would convince herself that polygamous marriages are part of her tradition.

Simone de Beauvoir states that "One is not born, but rather becomes, a woman"(18) ${ }^{3}$. She differentiates sex from gender. According to her the term 'female' refers to the natural facts, while the term 'woman' refers to something that has been constructed by the society. This means gender does not determine what makes a woman a woman. A woman learns her role from man and society. In her book, the Second Sex, she writes that the women's historical insignificance is not caused by their inferiority; it is rather their historical insignificance that has doomed them to inferiority (160).So Naze and Kader Ana were not born passive, secondary, and submissive, but the patriarchal ideologies of their environment shape them so. 
The patriarchal social structure has debilitated them and imposed on them a lower social status has with fewer rights and privileges, but with numerous responsibilities and obligations. It unreasonably favors men and works for their benefit at the expense of women. This type of ideology and characters is a result of deprivation of women and the whole society in education. If the society is educated, the patriarchal ideologies will change and the women will have the chance to be shaped into strong, independent woman, thus having a better life.

\subsection{Women's Unconsciousness about their Rights}

Women's unawareness about their rights is the second reason why women do not struggle against gender discrimination and patriarchy. They believe that their condition of subordination is natural, therefore, they are accustomed to it. They do not recognize that it is socially determined. In order to be able to challenge patriarchy, women have to notice that they are being oppressed by their patriarchal, male-dominated society and being marginalized from their basic human rights. Hooks states that before challenging patriarchy, people have to change themselves first; they have to raise their consciousness (7). Naze doesn't have a feminist consciousness; thus, she internalized the patriarchal ideology and embedded it in her daughters. Thus, patriarchy keeps on surviving in these rural areas.

Because of these two factors, patriarchy continues to prevail in these areas. However, patriarchy does not mean that men are not oppressed along other dimensions. Nor does it imply that men do not suffer under a patriarchal system that exploits them too. Patriarchal relations damage both men and women stunting men's emotional growth and oppressing women. Adem loses the girl he loves out of fear of patriarchal views. He is not courageous enough to break the traditional double standard rules and he makes a wrong decision. He suffers from his decision for the rest of his life and eventually suicides out of deep depression. Iskender too, loses his mother, family, and future because of patriarchal rules. Additionally, patriarchy is a factor contributing to Berzo's unhappy life. His wife is always anxious and irritated because she doesn't have a son, disturbing the welfare of the family, he is extremely sad not to have a son, and he loses his daughter, Hediye, sacrificing her for the code of honor. Lastly, Ahmet is another victim of patriarchy. He is deeply saddened by Gulbahar's behavior for he knows that he has to leave her and choose his honor over her, consequently losing the love of his life.

\subsection{Women's Resistance}

All the women in the three novels are portrayed as submissive characters to males and patriarchy. However, in each novel there is an exception. Jamila, in Honor, Gulbahar, in The Legend of Ararat, and Zelha, in Face to Face, are portrayed differently. For example in Honor, Jamila and Pembe are portrayed as victims of traditional society in which females have few choices in life. Both sisters were raised in the same environment by the same patriarchal ideologies, yet each one of them has a different character. They are identical in their physical appearances but completely different in personality. From the beginning of the novel, Jamila is presented as a strong female character who overcomes her struggle with gender issues. She has the inner strength to face her fears and accept life's challenges, rather than hiding under the security of a husband.

After the kidnappers bring Jamila back home, the family of the kidnappers declares that they did not lay a hand on her and Jamila never explained. Her father beats her several times but still Jamila keeps her silence. Adem also asks her to defend herself as it is shown in the conversation:

Your father says you may not be a virgin. 
He told you that? What about

you? She asked

What about me?

What did you say?

I want to know the truth?

The truth is what you make of it

Shut up. Stop fooling around

with me

But I was not. Will you love me the way I am?( Shafak 99).

Adem was not consented with Jamila's silence and does not answer her question. He decided to marry her twin Pembe, for Jamila has not sworn her chastity. What can be understood from Jamila's behavior is that she refuses to conform to patriarchal convictions and values. Her kidnapping is a stigma in areas inhabited by the Kurds and her honor could only be saved by marriage. Jamila does not see things that way. She wants to break the patriarchal laws and rules. Jamila is still a virgin and yet she remained quite against those false accusations of not having honor. Her silence represents her feminist consciousness in getting esteem from other people as a decent and respectable person for her character and who she is not for the code honor. She does not want to be defined by others and surely not by patriarchal ideologies which associate female to the code of honor. She wants to be respected and valued for what she does and not what has been done to her. Because even if she has lost her virginity, she is still a victim and her honor is pure as much as any other virgin girls who have not been kidnapped. Jamila has done nothing wrong and is not guilty; therefore she does not have to defend herself. Her only crime is being a female living in such an environment.

Jamila proves to be an intelligent, independent, strong, and a capable young woman. She could have defended herself and married Adem, and yet she does not. She knows if he has the least doubt about her honor, if he has these ideologies instilled in his mind, if he cares about trivial values more than his love for her; then she would lose her pride and respect for herself and would mean that she accepts the patriarchal belief of being merely a symbol of honor and a possession belongs to men. She sees that a loss of her personality in the name of security and saving her honor is worse than being a spinster. She has no concern for the opinions of others, and she does what she thinks is better for her. After Pembe and Adem got married, Jamila convinced her father to reject the widower and remains single because she could not marry for love. She becomes a midwife and lives alone in an area full of brigands, smugglers, and wolves. She was not scared of them, in her belief "danger always came from where it was least expected" (Shafak 36). This entails that danger comes from false overrated values of one's own society, from fathers who accept them, from mothers trying to implement them in their daughters, and from lovers and sisters who surrender to them.

Despite her harsh life, Jamila did not regret her decision and did not resent her life. Her only regret was not being able to become a doctor. If her circumstances were different, that would have been her goal. Unlike her sister and most of the village's girls, marriage was not her aim. She does not need a man to support her. Despite all the struggle and hardship she went through, she did not let the masculine society repress her individuality and identity and ultimately achieved autonomy by her persistence and determination.

Zelha in Face to Face is portrayed as a woman who resists the patriarchal ideologies. When her mother tries to convince her to marry the old man, Zelha threatens her mother that she will run away to the city and find a job there. She prefers to work as a servant than being forced to get married. She also tells her uncle that she will marry someone she loves. However nobody listens to her 
because in a patriarchal environment women have neither voice nor opinion in such matters. Therefore, she decides to elope even though she knows that the punishment is death for such an action.

$$
\begin{aligned}
& \text { God forbid you should } \\
& \text { fall in love with } \\
& \text { someone not } \\
& \text { considered suitable. } \\
& \text { Then the only solution } \\
& \text { is to put both your } \\
& \text { loves at risk because no } \\
& \text { matter how young you } \\
& \text { are, tribal laws dictate } \\
& \text { that, if you upset } \\
& \text { tradition, the penalty is } \\
& \text { death (Kulin 121). }
\end{aligned}
$$

She resists the patriarchal ideologies and refuses to submit to them. She wants to live a life of her own. She goes to the extent of risking her life rather than accepting her traditional role of being a submissive woman. She does not only resist these roles at her home but also at her husband's house. When he brings a second wife, she decides to return home rather than sharing her husband with another woman. She says: "when I tried to leave, he begged me to stay explaining that polygamous marriages were part of our tradition anyway" (Kulin 71). Again, she refuses these traditional rules and "went back to the farm"(Kulin 75).Even though she knows she may face the penalty of death by her family for eloping. She is portrayed as a strong character that does not fear to resist her society's rules despite the fact that in her environment resisting may cause her death. She is also portrayed as an ambitious girl determined to finish her education despite all the obstacles she faces. Since she was a little girl, she loved going to school. Not having a primary school at her village did not make her give up her dream of continuing her education. She studied at home and took exams to finish her primary school till she eventually got her diploma.

Gulbahar, in The Legend of Ararat, is another character who is depicted as a woman who resists her traditional gender role. She helps the old Sofi in prison and bring him food every day. Her father commands her: "you will have nothing more to do with that old man" (Yashar 33). She disobeys her father's orders and keeps on helping him secretly. She defies her father's rules in order to do what is right. And when Ahmet gets imprisoned for not returning the horse; she goes to Huso, the smith, and the Sheikh and asks for their help. Huso returns the horse to her father, but her father insists on killing the prisoners:

$$
\begin{aligned}
& \text { With all due respect to } \\
& \text { the Sheikh, I tell you it's } \\
& \text { not my horse. And for } \\
& \text { that reason, I shall have } \\
& \text { them beheaded } \\
& \text { tomorrow Saturday at } \\
& \text { dawn (Kemal 81). }
\end{aligned}
$$

Therefore, she arranges for the prisoners' escape, with Memo, the dungeon's guard. She knows the penalty of defying her father's rules is death; however, she keeps resolute to save the prisoners for she realizes that they are innocent. She is unlike other girls who naively accept and submit to the male rules, even if these rules are immoral.

She is even more courageous than her brother Yusuf. When she asks for his help, he refuses out of fear of their father. He says:

Everyone fears him,
even the Shah and the
Padishah...only that
wretched Gulbahar is
not afraid of him, and
Huso the smith. What
about the Sheikh of the 
caravans...? No, even

he fears the Pasha

(Kemal 94).

Eventually, Yusuf breaks his sister's secret to his father fearing of his tyranny:

What if he said, my own son was aware of all these goings-on and he never told me! He dared defy me! I must make an example of him in the town square or die myself. I must have his eyes gouged out. He shall be skinned alive...or I will die (Kemal 94).

It can be said that Gulbahar is portrayed as a heroine because she has all the elements of heroism. According to Franco and Zimbardo, heroes are those who risk their lives for others. The researchers Rankin and Eagly ${ }^{5}$ include benefiting others and acting selflessly as additional elements of heroism(Klisanin2). Therefore, Gulbahar is represented as a heroine because she risks and endangers her life to save those in need. She breaks away from her traditional gender role, expectations, and fate and chooses to be sacrificial in nature.

\subsection{Double- Oppression}

Women in these novels are double oppressed. They are victims of both the Turkish government, which devalues them because of their race and cultural ancestry, and the patriarchal ideology, which devalues them because of their gender. The Kurdish villages are deprived from basic human facilities such as schools and hospitals because these villages are inhabited by Kurds. Hence, the Kurdish women's civil human rights are denied. A Kurdish woman does not have the chance of having a successful comfortable life as a Turkish woman has. Being Kurdish in Turkey means being doomed to struggle and suffer for life. Nevra says:"We were both born in the same country, but I grew up with all the privileges that my poor friend couldn't even imagine" (Kulin 82). So because Nevra is Turkish, She has the privileges that her Kurdish friend doesn't have.

Moreover, women are oppressed by men because patriarchal norms promote the belief that women are innately inferior to men. Hence, women in Turkey, because they are females and Kurds, suffer from double oppression and face educational deprivation, racism, and deprivation from health facilities.

\section{8 Women and Health}

Shafak and Kulin present the issue of women favoring delivery at home. Women's preference to give birth at home with the help of the midwife rather than going to a facility for her delivery is due to various physical and socioeconomic barriers including long distances, poor road conditions, and lack of money for transport. Mala Car Bayan village has no hospitals. The nearest hospital to this village is within ninety kilometers. If a pregnant woman wants to deliver at the hospital, she has to take a minibus, then a bus, till she reaches the city.

Moreover, most women have a positive attitude towards Kurdish midwives and perceive them to be respectful, skilled, friendly, and trustworthy, and negative attitude towards the Turkish doctors and quality of services provided at the hospital. Indeed, the midwife treats the women with kindness and compassion while Turkish doctors treat Kurds cruelly as if they are inferior human being. On the other hand, Lack of education, illiteracy, and unawareness regarding delivery complications contribute to women preferring delivery at home. Most of the women in the area are illiterate and do not have appropriate knowledge regarding maternal health.

Other important factors that contribute to home delivery 
are: women's lack of decision- making regarding childbirth, dependence on the husband and other family members for the final decision, and the prevalence of traditional views. These factors work as obstacles from delivering at a hospital. Often the mother-in-law prohibits her daughter-in-law from going to a hospital because she herself did not go to a hospital for delivery. The following quote illustrates this underlying view.

$$
\begin{aligned}
& \text { Siyar had promised to } \\
& \text { send me to the hospital } \\
& \text { when it was due and he } \\
& \text { kept his promise. Can } \\
& \text { you imagine woman? I } \\
& \text { gave birth to my baby } \\
& \text { in a hospital! Who ever } \\
& \text { heard of the likes of us } \\
& \text { having babies in a } \\
& \text { hospital? Most of my } \\
& \text { husband's relatives } \\
& \text { were angry that I } \\
& \text { hadn't had the baby at } \\
& \text { home with the help of a } \\
& \text { midwife but he } \\
& \text { wouldn't hear of it } \\
& \text { (Kulin } 79 \text { ). }
\end{aligned}
$$

All of these challenges are important reasons for home delivery in these Kurdish regions . And the consequences are devastating. Many mothers die due to complications during the delivery. Naze and her child die during the delivery, if she delivered at a hospital, two lives would have been saved. Furthermore, women suffer from having many miscarriages because of the lack of appropriate health care system. Naze had five miscarriages, and Kader Ana also suffers from many miscarriages.

'But surely Kader Ana could have had another baby, why didn't she?'

'She did try but she

kept on having

miscarriages'(Kulin

117).

\section{Conclusion}

Shafak has presented some of the Kurdish women as naïve and submissive to the patriarchal ideologies that rule their areas; however, she apparently doesn't seek to present a negative image of Kurdish women. She endeavors to imply that these women are naïve because of their conditions that deprived them from education and the prevalence of patriarch male dominant society. She brings to attention the harsh reality that these women do not realize that they are submissive and are not aware of their rights. Shafak assumes that if these Kurds had been given the same opportunities and rights as the Turks have, Kurdish women would be in better conditions and their submissiveness will turn to independence; and the patriarchal principles that exist in these areas will start to abolish. On the other hand, Shafak presents some of the Kurdish women characters who develop and gain strength and independence as the events unfold, despite their underprivileged conditions and harsh realities. Their power comes from the fact that they have had access to education.

Similarly, Kulin has presented the uneducated women as naïve and victims of patriarchy, while the educated women as strong and clever. Again, Kulin emphasizes the fact that the existence of these patriarchal values can be attributed to their illiterate environment and lack of awareness. Likewise, Kemal has presented the Kurdish woman in his novel as a strong, intelligent and independent who doesn't surrender to her submissive role and resists patriarchal ideologies. On the other hand, the novelists have attempted to engage the reader in the victimization of the Kurdish women characters 
and challenge the stereotype images of Kurdish women

in the writings of authors who misrepresented the Kurds. Besides, the authors have utilized the characterization of some Kurdish characters in their works to criticize Turkey's policies towards the Kurds and called for changes on personal, social, and political levels to be equally treated as citizens of the state.

\section{References}

1. Adli, Feyza Burak. "The Veiled Periphery: Rural Kurdish Women in Turkey and Taboo of Sexuality" Student Anthropologist 3(2012): 47-61. Web 12 Apr 2016.

2. Beauvoir, Simone. The Second Sex. New York: Vintage, 2010.

3. Bernu, Rachel, et al. The Increase in Kurdish Women Committing Suicide. Rep. no. 393.248. Ed. Pranjali Acharya, et al.. London: KURDISH HUMAN RIGHTS PROJECT, 2007. THE INCREASE IN KURDISH WOMEN COMMITTING SUICIDE. The European Parliament's committee on Women's Rights and Gender Equality,June2007<www.europarl.europa.eu/RegData/e tudes/.../IPOL-

FEMM_ET(2007)393248_EN.pdf>.Accessed on March 2016

4. Cross, Susan E. "Cultural Prototypes and Dimensions of Honor." Personality and Social Psychology Bulletin 40(2) (2012): 232-49. Web. 24 Nov. 2016.

a. <

public.psych.iastate.edu/caa/Classes/Readings/14Cross etalCultureHonor.pdf>.

5. Global Initiative. Corporal punishment of children in Turkey. Rep. N.p.: n.p., n.d. End corporal punishment/Corporal punishment of children in Turkey. Global Initiative. Web. 4 Apr. 2016.

6. Greer, Germaine. The Female Eunuch. USA: Harper Collins, 1991.

7. Hooks, Bell. Feminism is for Everyone. Canada: South End Press, 2009.

8. Kemal. Yashar. The Legend of Ararat. London: Collins and Harvill Press, 1975.

9. Klisanin, D. "The Hero and the Internet: Exploring the Emergence of the Cyberhero Archetype" Media Psychology Review 4(2012).Web 5 May 2016

10. Kulin, Ayşe. Face to Face. Istanbul, Everest, 2006.

11. Saarinen, Tuija" General cultural differences and stereotypes: Kurdish family culture and customs" Saarinen Tuija. Web 17 Apr 2016.

12. Shafak, Elif. Honor. Penguin books: New York, 2012.

13. Stevenson, Julianne. The Situation of Kurdish Childrenin Turkey. Rep. Ed. Rachel Bernu, Michael Farquhar, and
Mustafa Gündoğdu. London: KURDISH HUMAN RIGHTS PROJECT, 2008. 1 Mar. 2016.

14. Walby, Sylvia. Theorizing Patriarchy. Oxford: Blackwell, 1990. 